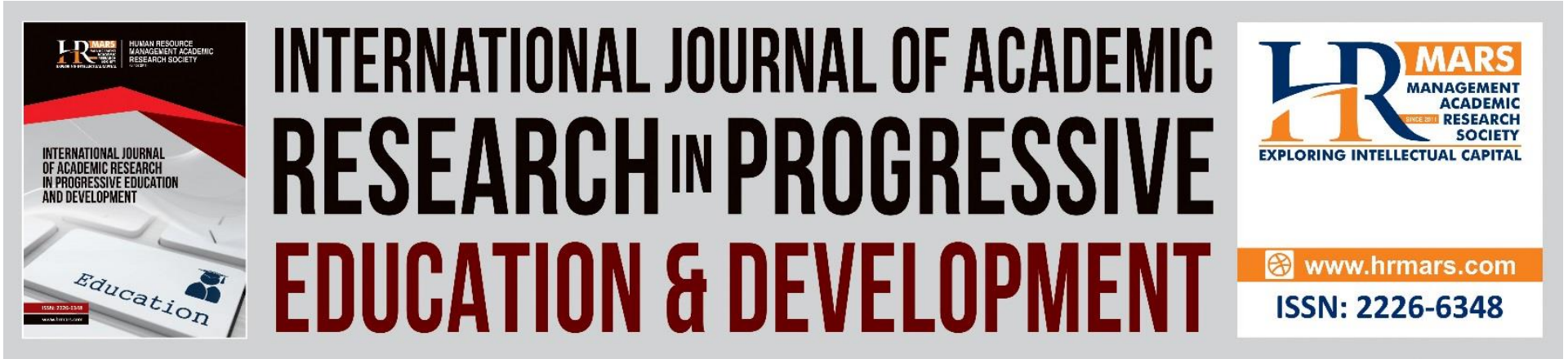

\title{
A Systematic Review to Identify EFL Teachers' Training Needs for Professional Development Programs
}

\author{
Mona Abdullah Alzahrani, Faizah Muhamad Nor
}

To Link this Article: http://dx.doi.org/10.6007/IJARPED/v10-i3/10558

DOI:10.6007/IJARPED/v10-i3/10558

Received: 10 June 2021, Revised: 14 July 2021, Accepted: 27 July 2021

Published Online: 16 August 2021

In-Text Citation: (Alzahrani \& Nor, 2021)

To Cite this Article: Alzahrani, M. A., \& Nor, F. M. (2021). A Systematic Review to Identify EFL Teachers' Training Needs for Professional Development Programs. International Journal of Academic Research in Progressive Education and Development, 10(3), 130-139.

Copyright: (C) 2021 The Author(s)

Published by Human Resource Management Academic Research Society (www.hrmars.com)

This article is published under the Creative Commons Attribution (CC BY 4.0) license. Anyone may reproduce, distribute, translate and create derivative works of this article (for both commercial and non-commercial purposes), subject to full attribution to the original publication and authors. The full terms of this license may be seen

at: http://creativecommons.org/licences/by/4.0/legalcode

Vol. 10(3) 2021, Pg. 130 - 139

http://hrmars.com/index.php/pages/detail/IJARPED

JOURNAL HOMEPAGE

Full Terms \& Conditions of access and use can be found at http://hrmars.com/index.php/pages/detail/publication-ethics 


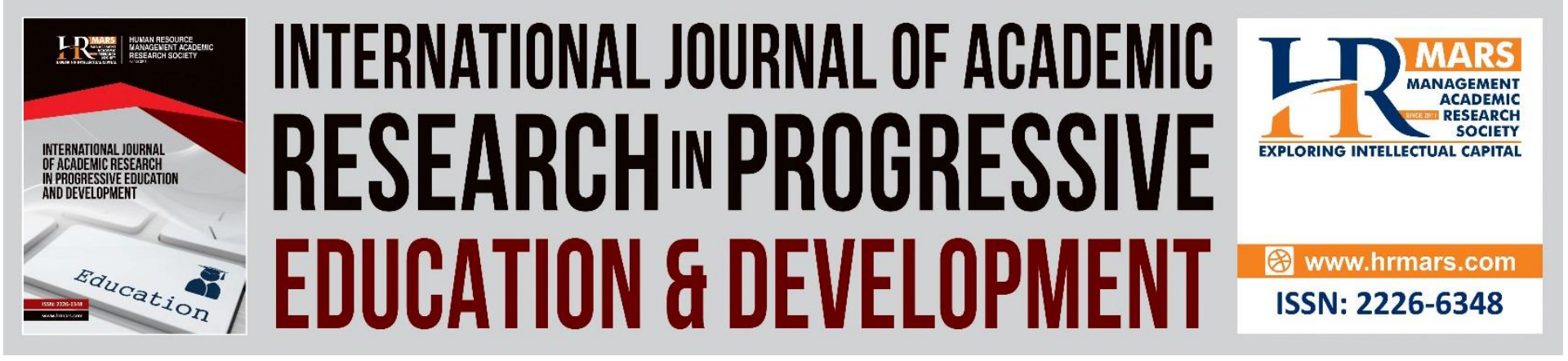

\title{
A Systematic Review to Identify EFL Teachers' Training Needs for Professional Development Programs
}

\author{
Mona Abdullah Alzahrani, Faizah Muhamad Nor \\ TESL Department, University Technology Malaysia, Johor Bahru, Malaysia \\ Email: mona2007za1428@hotmail.com
}

\begin{abstract}
As being an international language, English is described as a communication tool all over the world. The field of teaching this language is affected by the changeable characteristics of this technological era. Therefore, learners and teachers are changing and in order to meet the demands of this change, teachers must keep up to date and improve their teaching practices and beliefs. This can be done through professional development programs (PDPs) and inservice training for English as foreign Language (EFL) teachers. The purpose of this systematic review was to identify EFL Teachers' needs for PDPs. A total of 11 empirical studies were chosen for thorough review upon detailed selection criteria. The reviewed papers were related to in-service EFL teachers' training needs in journal articles published between 2015 and 2019. In this review, methods and results of different research studies were analyzed via a collection of systematic techniques. The results of the study indicated that there were eight categories of EFL teachers' needs for PDPs. Through this systematic review, authors provided recommendations for researchers and PDPs designers.
\end{abstract}

Keywords: English as a Foreign Language, EFL Teachers' Professional Needs, Teacher Training Programs, Professional Development, Teacher Education

\section{Introduction}

Education has always been one of the important systems in any society and it brings positive change in the social, political, economic, and cultural life of people. This powerful system consists of many important agents and teacher is one of them. Teachers play a necessary role in the education field that's why they need to be prepared well and continuously since knowledge is not something static. Although some teachers try to develop themselves by self-learning, having systematic professional development programs (PDPs) conducted by experts for teachers in schools and universities is something very essential. If teachers are not included in such training, they may stay behind professionalism (Spencer et al., 2018).

Evişen (2021) stated that EFL teachers considered professional development as a way for self-improvement. Thus, teacher training is a basic resource to implement improvements 
and professionalism to the education system. It leads to professional development in teachers' performance and then learning results (Boudersa, 2016). Professional development is defined as structured professional learning that changes teacher practices. It is needed to help teachers learn and improve their knowledge and instructions required to teach $21^{\text {st }}$ century skills (Darling-hammond et al., 2017). Therefore, because teachers are the first decision makers in their classrooms, they will face the challenge of having inadequate subject knowledge and pedagogical skills to teach a given subject and provide the learner with the appropriate knowledge if they do not receive adequate training (Boudersa, 2016).

Although some teachers consider themselves to be knowledgeable and confident, they have a gap perception between their current knowledge and what they need to know to become an expert teacher because of the new challenges (Moeini, 2008). However, having the knowledge is not enough to be professional in teaching. Teachers need to transfer this knowledge into practices at their classrooms to have an effective PDP and this is what is called the impact of PDPs on teachers' knowledge and skills. Another issue regarding the effectiveness of any PDP is that it should meet the teachers' needs in order to have the required PD that improves teachers' practices and skills. It is believed that this is a main step to determine whether training is needed and, if so, to specify what that training should provide. The literature indicated that designing PDPs in a bottom-up approach that is based on teachers' needs is more valuable than a top-down approach (Darling-hammond et al., 2017; Macias, 2017). Thus, an effective approach for conducting PDPs is to have a needs assessment for teachers before designing ant training program (Powell \& Bodur, 2019).

As a step forward to identify EFL teachers' training needs for PDPs, this systematic review of literature is very timely. Most of the institutions nowadays are conducting training programs for their teachers in order to follow the rapid change of knowledge. Training, alone, cannot make miracles; teachers need to be aware of what they want and lack to help them develop themselves no matter what obstacles they find in their teaching environment. It is essential to design the PD programs with teachers' needs in mind. By not involving the teachers' needs in the PD programmes structuring and design, the teachers will not have the chance to any important input (Alammari, 2019; Mansory, 2019). Thus, the aim of this systematic review was identifying the training needs of EFL teachers that should be addressed in PDPs.

\section{Methodology}

In order to be included in this systematic review of literature, the articles had to meet certain criteria put by the researcher to eliminate the non-related articles and to have an intensive review of the selected articles. These criteria were: the articles should be published between 2015 to 2019, include participants from institutions in countries who teach English as a foreign language (EFL), and the research's samples must be in-service teachers. Also, the articles should be published in English language, and online.

For identifying the articles that were included in this review, several online databases were searched. The search was conducted through using the UTM library website and Google Scholar. The electronic databases including Taylor \& Francis, Web of Science, Sciencedirect, SpringerLink, Wiley, and Scopus were searched. EFL teachers' professional needs, professional development, in-service training, English Language teachers, teacher education search terms were used. The search was performed by using the 'keyword' function. All 
DEVELOPMENT

Vol. 10, No. 3, 2021, E-ISSN: 2226-6348 @ 2021 HRMARS

databases were searched for the period of 2015 to 2019. The search resulted in 211 total number of documents which were examined preliminarily. Through the initial scanning, the exclusion criteria were applied. All documents that included PDPs or in-service teachers of general education or non-ELT fields, pre-service teachers, and non-English studies were eliminated. After examining the abstracts of each study initially, the researcher applied the inclusion criteria to select the studies that could be included within the scope of this study. Through this process, eleven journal articles were selected for further examination. Figure 1 illustrates the methodology of articles selection.

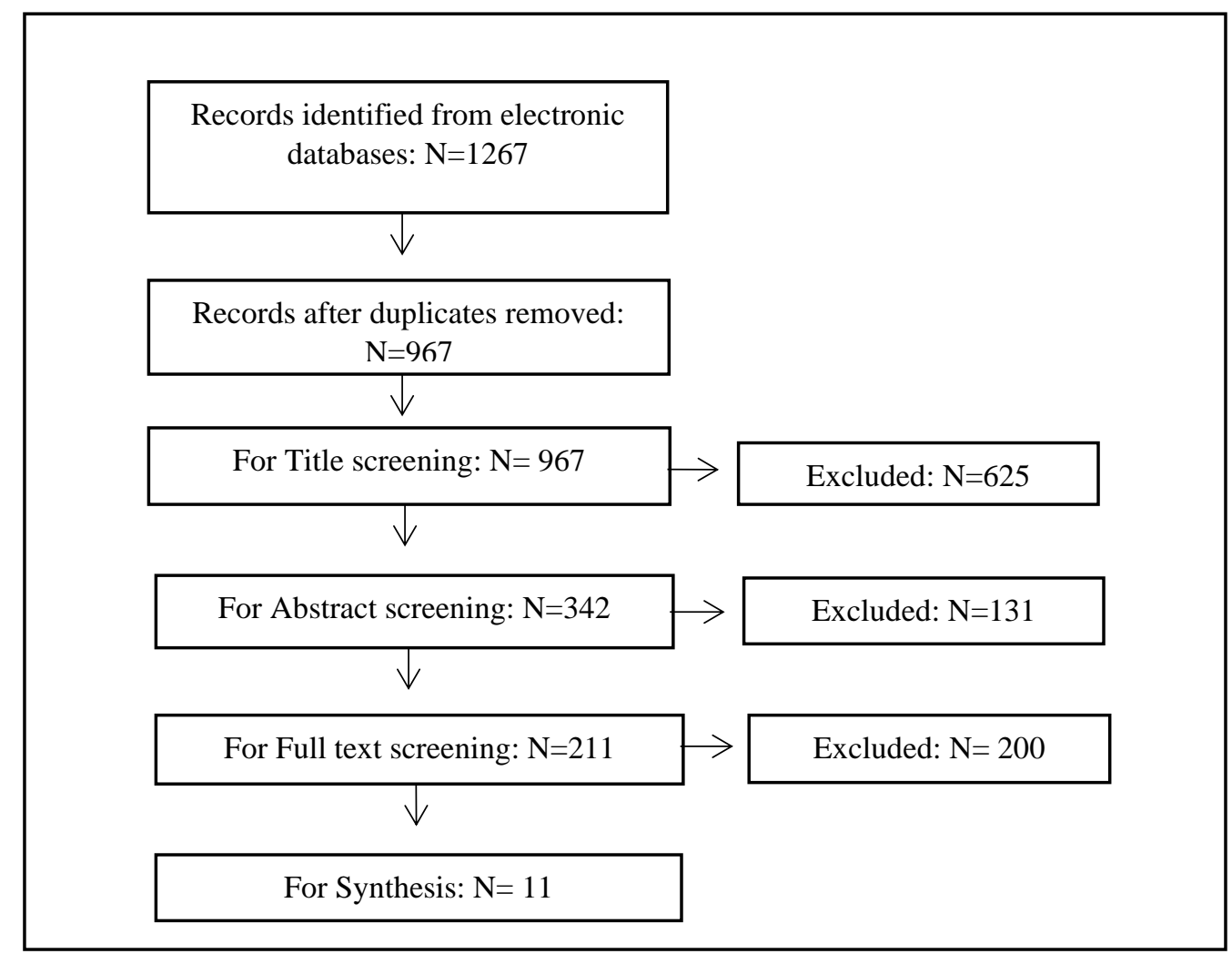

Figure 1. Methodology of Articles Selection.

It could be seen from Figure 1 that the number of articles that were resulted from the electronic databases were 1267. Then, the duplicates were removed, and the number of articles decreased to 967. After that, the titles of these 967 articles were screening to withdraw the unrelated ones. 625 articles were excluded to have a number of 342 articles for abstract screening. After reading the abstracts of these chosen articles, 131 articles were excluded to have 211 articles for full text screening. Finally, 200 articles were excluded to have 11 articles for intensive synthesis to extract the training needs of EFL teachers.

\section{Results and Discussion}

Through an in-depth analysis of each document of the eleven research papers, it became apparent that there were eight categories in which EFL teachers' needs can fall. These categories were: teaching skills, assessment literacy, management skills, content knowledge, educational psychology, IT literacy skills, material development, and research skills. Table1 provides a detailed view of the studies that were included in this systematic review with the categories. 
INTERNATIONAL JOURNAL OF ACADEMIC RESEARCH IN PROGRESSIVE EDUCATION AND DEVELOPMENT

Vol. 10, No. 3, 2021, E-ISSN: 2226-6348 @ 2021 HRMARS

Table 1. The Categories of EFL Teachers' Training Needs

\begin{tabular}{|c|c|c|}
\hline Category & Items & Articles \\
\hline \multirow{6}{*}{$\begin{array}{l}\text { Teaching } \\
\text { Skills }\end{array}$} & Classroom activities & $\begin{array}{l}\text { Shabani, et al (2019); Oudah \& Altalhab } \\
\text { (2018); Spencer, et al (2018) }\end{array}$ \\
\hline & Innovations in teaching & Shabani, et al. (2019) \\
\hline & $\begin{array}{l}\text { Developing listening, } \\
\text { reading, speaking, and } \\
\text { writing }\end{array}$ & $\begin{array}{l}\text { Arslan, Mirici, \& Hüseyin (2019); Shabani, et } \\
\text { al (2019); Raud \& Orehhova (2017); Zein } \\
\text { (2016); Koç, et al (2015) }\end{array}$ \\
\hline & $\begin{array}{l}\text { Teaching vocabulary } \\
\text { and grammar }\end{array}$ & $\begin{array}{l}\text { Arslan, Mirici, \& Hüseyin (2019); Shabani, et } \\
\text { al (2019); Raud \& Orehhova (2017); Koç, et al } \\
\text { (2015) }\end{array}$ \\
\hline & $\begin{array}{l}\text { Teaching methods and } \\
\text { techniques }\end{array}$ & $\begin{array}{l}\text { Hazaea (2019); Shabani, et al (2019); Spencer, } \\
\text { et al (2018); NaliakaMukhale \& Hong (2017); } \\
\text { Raud \& Orehhova (2017); Zein (2016); Koç, et } \\
\text { al (2015); Lich (2015) }\end{array}$ \\
\hline & $\begin{array}{l}\text { Teaching large /mixed } \\
\text { ability classes }\end{array}$ & $\begin{array}{l}\text { Arslan, Mirici, \& Hüseyin (2019); Shabani, et } \\
\text { al (2019); Spencer, et al (2018); } \\
\text { NaliakaMukhale \& Hong (2017); Zein (2016) }\end{array}$ \\
\hline \multirow[t]{2}{*}{$\begin{array}{l}\text { Assessment } \\
\text { Literacy }\end{array}$} & $\begin{array}{l}\text { Assessment and } \\
\text { grading strategies }\end{array}$ & $\begin{array}{l}\text { Shabani, et al (2019); Czerniawski, et al } \\
\text { (2018); Oudah \& Altalhab (2018); } \\
\text { NaliakaMukhale \& Hong (2017); Raud \& } \\
\text { Orehhova (2017); Zein (2016); Koç, et al } \\
\text { (2015) }\end{array}$ \\
\hline & $\begin{array}{l}\text { Error correction and } \\
\text { Feedback provision }\end{array}$ & Spencer, et al (2018); Zein (2016) \\
\hline \multirow{3}{*}{$\begin{array}{l}\text { Management } \\
\text { Skills }\end{array}$} & $\begin{array}{l}\text { Behaviour } \\
\text { Management }\end{array}$ & Shabani, et al (2019); Spencer, et al (2018) \\
\hline & $\begin{array}{l}\text { Creating relaxed } \\
\text { atmosphere }\end{array}$ & Spencer, et al. (2018) \\
\hline & $\begin{array}{l}\text { Management } \\
\text { strategies }\end{array}$ & $\begin{array}{l}\text { Arslan, Mirici, \& Hüseyin (2019); Hazaea } \\
\text { (2019); Shabani, et al (2019); Spencer, et al } \\
\text { (2018); NaliakaMukhale \& Hong (2017); Raud } \\
\text { \& Orehhova (2017) }\end{array}$ \\
\hline \multirow{3}{*}{$\begin{array}{l}\text { Language/ } \\
\text { Content } \\
\text { Knowledge }\end{array}$} & Language proficiency & $\begin{array}{l}\text { Shabani, et al (2019); Oudah \& Altalhab } \\
\text { (2018); Raud \& Orehhova (2017); Zein (2016) }\end{array}$ \\
\hline & Pronunciation & Raud \& Orehhova (2017); Zein (2016) \\
\hline & $\begin{array}{l}\text { Language acquisition } \\
\text { and Improvement }\end{array}$ & $\begin{array}{l}\text { Shabani, et al (2019); Oudah \& Altalhab } \\
\text { (2018); Raud \& Orehhova (2017); Zein (2016) }\end{array}$ \\
\hline \multirow{5}{*}{$\begin{array}{l}\text { Educational } \\
\text { Psychology }\end{array}$} & Students' confidence & Shabani, et al (2019); Zein (2016); Lich (2015) \\
\hline & Students' autonomy & Shabani, et al (2019); Zein (2016); Lich (2015) \\
\hline & Students' motivation & Shabani, et al (2019); Zein (2016); Lich (2015) \\
\hline & $\begin{array}{l}\text { Establishing rapport } \\
\text { with students }\end{array}$ & Shabani, et al (2019); Spencer, et al (2018) \\
\hline & $\begin{array}{l}\text { Teacher teaching self- } \\
\text { efficacy }\end{array}$ & Shabani, et al (2019) \\
\hline
\end{tabular}


INTERNATIONAL JOURNAL OF ACADEMIC RESEARCH IN PROGRESSIVE EDUCATION AND DEVELOPMENT

Vol. 10, No. 3, 2021, E-ISSN: 2226-6348 @ 2021 HRMARS

\begin{tabular}{|c|c|c|}
\hline & $\begin{array}{l}\text { Teachers' teaching } \\
\text { motivation }\end{array}$ & Shabani, et al (2019) \\
\hline \multirow{3}{*}{$\begin{array}{l}\text { IT Literacy } \\
\text { Skills }\end{array}$} & Online teaching & $\begin{array}{l}\text { Hazaea (2019); NaliakaMukhale \& Hong } \\
\text { (2017) }\end{array}$ \\
\hline & Integrating technology & $\begin{array}{l}\text { Arslan, Mirici, \& Hüseyin (2019); Shabani, et al } \\
\text { (2019); Czerniawski, et al (2018); } \\
\text { NaliakaMukhale \& Hong (2017); Koç, et al } \\
\text { (2015) }\end{array}$ \\
\hline & Online learning & NaliakaMukhale \& Hong (2017) \\
\hline \multirow{4}{*}{$\begin{array}{c}\text { Material } \\
\text { Development }\end{array}$} & $\begin{array}{l}\text { Curriculum } \\
\text { development/ } \\
\text { adaptation/ adoption }\end{array}$ & $\begin{array}{l}\text { Arslan, Mirici, \& Hüseyin (2019); Hazaea } \\
\text { (2019); Shabani, et al (2019); Czerniawski, et al } \\
\text { (2018) }\end{array}$ \\
\hline & Lesson planning & $\begin{array}{l}\text { Shabani, et al (2019); Raud \& Orehhova } \\
\text { (2017); Zein (2016); Koç, et al (2015) }\end{array}$ \\
\hline & Book evaluation & $\begin{array}{l}\text { Shabani, et al (2019); Spencer, et al (2018); } \\
\text { Raud \& Orehhova (2017); Zein (2016); Koç, et } \\
\text { al (2015) }\end{array}$ \\
\hline & $\begin{array}{l}\text { English teaching aids/ } \\
\text { supplement materials/ } \\
\text { resources }\end{array}$ & $\begin{array}{l}\text { Hazaea (2019); Shabani, et al (2019); Oudah \& } \\
\text { Altalhab (2018); Raud \& Orehhova (2017); Zein } \\
\text { (2016) }\end{array}$ \\
\hline \multirow{3}{*}{$\begin{array}{l}\text { Research } \\
\text { Skills }\end{array}$} & Research writing skills & $\begin{array}{l}\text { Hazaea (2019); Czerniawski, et al (2018); } \\
\text { Spencer, et al (2018); NaliakaMukhale \& Hong } \\
\text { (2017) }\end{array}$ \\
\hline & Journal Publications & $\begin{array}{l}\text { Hazaea (2019); Czerniawski, et al (2018); } \\
\text { NaliakaMukhale \& Hong (2017) }\end{array}$ \\
\hline & $\begin{array}{l}\text { Presenting at } \\
\text { Conferences }\end{array}$ & $\begin{array}{l}\text { Hazaea (2019); Czerniawski, et al (2018); } \\
\text { Spencer, et al (2018); NaliakaMukhale \& Hong } \\
\text { (2017); Koç, et al (2015) }\end{array}$ \\
\hline
\end{tabular}

It could be seen from Table 1 that the needs of EFL teachers for PDPs were categorized in eight constructs depending on the systematic review of the eleven articles. The first category is teaching skills which was agreeable by all the articles (e.g., Hazaea, 2019; Oudah \& Altalhab, 2018; and Raud \& Orehhova, 2017; Shabani et al., 2019) with different subheadings. In the field of teaching, there is no doubt that all teachers should master the skills that enable them to deliver the content to their students in an effective way. Boudersa (2016) stated that teacher training that would be included in professional development programs should focus on teaching skills. The next category is assessment literacy which was found in most of the reviewed articles such as( Czerniawski et al., 2018; Oudah \& Altalhab, 2018; Shabani et al., 2019). Although assessment literacy is related to teaching skills in one way or another, some researchers preferred to separate it in a different section of EFL teachers' needs which ensures its important to be trained on. The quality of learning and student achievement will be impacted by the assessment's success; therefore, teachers must have good assessment literacy (Zulaiha \& Mulyono, 2020).

Management skills were another category which classified as EFL teachers' needs in Arslan et al., 2019; Hazaea, 2019; NaliakaMukhale \& Hong, 2017; Raud \& Orehhova, 2017; 
Shabani et al., 2019; Spencer et al., 2018; Zein, 2016. It was indicated in GAKWERERE, HARERIMANA, \& MUKAMAZIMPAKA (2020) that the student dropout rate were affected by classroom management's strategies. The findings of this study claimed that education associates should have periodical training sessions for teachers to encourage effective classroom management strategies in order to enhance teachers' professional practice and knowledge and to encourage students to continue their learning. The following category of EFL teachers' needs for PDPs was content knowledge. Czerniawski, et al (2018); Koç, et al (2015); and Shabani et al (2019) mentioned that EFL teachers need to know about the contextual and curriculum content in a professional way in order to achieve the intended learning outcomes. Furthermore, the participants in Zein's (2016) study stated that regardless of novice teachers' educational background, they needed contextual knowledge.

Educational psychology is the next category which was identified in this process of reviewing. It included both teachers and learners. The studies of (Lich, 2015; Shabani et al., 2019; Spencer et al., 2018; Zein, 2019) emphasized the importance of learners' knowledge as they are the ones who will receive the material from the teachers. Therefore, teachers should be prepared to know their learners' needs, characteristics and ways for motivating them to learn. Furthermore, and as mentioned in the reviewed articles, teachers have also to be trained on self-efficacy and motivation in order to more confident while delivering the lessons to their students. Xin, Wilfried \& Nadira (2021) mentioned that teachers' self-efficacy in the classroom is linked to their intrinsic motivation to learn. This indicates that the more confident teachers are in their ability to teach, the more likely they are to engage in professional development.

Information technology (IT) literacy is another category of EFL teachers' training needs that have been discussed in six of the reviewed articles. Although the concept of educational technology as a teaching tool in language classes is not new to everyone, many teachers are unfamiliar with it, and specific software applications and other tools are even more novel in some situations. (Nicholls, 2018). Therefore, both old and novice teachers should be trained in IT literacy in order to cope with the new developmental context in the field of education.

Next, is the material development which described by most of the reviewed articles as another important EFL teachers' needs to be included in training sessions. In Arslan et al (2019), material development came in the most frequently listed need that was mentioned by the study sample. Furthermore, in Zein (2019) teacher educators stated that although materials selection was restricted by the use of coursebooks designed by educational administrators, teachers needed to attend training on teaching materials selection and adaptation in order to be more confident. Finally, research skills were categorized as EFL teachers' training needs by five of the reviewed articles. In Czerniawski et al. (2018) research skills appeared in the next frequently noted list of the professional needs for EFL teachers. Similarly, Hazaea (2019) found that EFL teachers need more training workshops on research activities such as research methodology and journal publications.

\section{Limitations and Implications}

There are some limitations to this article. First, this systematic review was limited to only studies conducted within the years of 2015 -2019, therefore they may not be a representative of other contexts. Secondly, the sample for this study was limited to EFL 
DEVELOPMENT

Vol. 10, No. 3, 2021, E-ISSN: 2226-6348 @ 2021 HRMARS

teachers. So, the results cannot be generalized to other subjects. The other limitation is that this review included only studies published as a journal article in the English language. Finally, due to the limited number of studies found in this area, there was not effort to eliminate studies of less quality.

Despite the previous limitations, the results of this systematic review can serve as a guide to future research in the area of designing EFL teachers training programs. As clearly stated in the review, there are limited research in the field that concern about EFL teachers' needs in planning these programs. That is why there is a persistent need to fill in this gap. The following implications should be taken into consideration for further research:

(1) The real needs of teachers' must be met through PDPs. Thus, future planning of these programs should pay attention to the teachers' input.

(2) PDPs should be offered regularly and consistently with the updating of teachers' needs as the field of education changed rapidly.

(3) More efforts in designing PDPs should be put on the category of pedagogy as it is the core of the educational context.

(4) Teachers should be given an opportunity to evaluate and reflect on PDPs.

(5) There should be a unit of PD in any educational institution which is responsible for planning and designing PDPs for specific subject areas such as English language. The coordinators of this unit shall be teachers with experience from the field.

\section{Conclusion}

The general aim of this systematic review was to identify the training needs of EFL teachers that should be addressed in PDPs; and to offer recommendations and suggestions for future research in this area. To conduct this review, several databases such as Taylor \& Francis, Web of Science, and Scopus were scanned with key words were selected for the purpose of this study. After the in-depth analysis of the databases and readings, eleven articles were chosen to be examined. The publications were read deeply and coded under different categories. Then, they were presented and discussed under the eight categories that have been illustrated in the results section.

These key findings have theoretical and contextual contribution in the field of PDPs at higher education institutions where EFL teachers work. They can help the PDPs' designers at the universities to include these identified EFL teachers' needs in the training sessions they plan for their teachers to have the required change. Based on the assumptions of adult learning theory of Malcom Knowles, adults are able to learn things they need to know (Knowles, Holton \& Swanson, 2014). Thus, learning will not happen till there is a need for it. Additionally, it has a significant contribution to an area that is widely accepted as an important issue for research in the teacher education field in the foreign language settings. This area is the professional development context that leads to a lifelong learning process for every teacher.

\section{Funding}

This research received no external funding.

\section{Conflicts of Interest}

The author declares no conflict of interest. 
DEVELOPMENT

Vol. 10, No. 3, 2021, E-ISSN: 2226-6348 @ 2021 HRMARS

\section{References}

Alammari, F. A. A. (2019). Qualitative Study of Continuous Professional Development of English Language Teachers: Perceptions and Practices. Research Journal of English Language and Literature, 7(1), 344-354. https://doi.org/10.33329/rjelal.7119.344

Arslan, S., Mirici, İ. H., \& Hüseyin, Ö. Z. (2019). In-service training needs of EFL teachers in nonformal education settings. Selçuk Üniversitesi Edebiyat Fakültesi Dergisi, (42), 223-244. https://doi.org/10.21497/sefad.675203

Boudersa, N. (2016). The importance of teachers' training programs and professional development in the Algerian educational context: Toward informed and effective teaching practices. Expériences Pédagogiques, 1(1), 1-14. https://www.researchgate.net/publication/309430087

Czerniawski, G., Gray, D., MacPhail, A., Bain, Y., Conway, P., \& Guberman, A. (2018). The professional learning needs and priorities of higher-education-based teacher educators in England, Ireland and Scotland. Journal of Education for Teaching, 44(2), 133-148. https://doi:10.1080/02607476.2017.1422590

Darling-Hammond, L., Hyler, M. E., \& Gardner, M. (2017). Effective teacher professional development. Learning Policy Institute.

Evişen, N. (2021). Turkish in-service and pre-service EFL teachers' views on professional development and related activities. Focus on ELT Journal, 3(1), 43-64. https://doi.org/10.14744/felt.2021.00048

Gakwerere, M. C., Harerimana, J. P., \& Mukamazimpaka, M. C. (2020). Classroom Management Strategies and Students' Drop out in Public Secondary Schools in Rwanda, a Case of Musanze District, Journal of Education, Vol. 3(6), 53-75.

Hazaea, A. (2019). The needs on professional development of English language faculty members at Saudi University. International Journal of Educational Researchers, 10(1), 1-14.

Knowles, M. S., Holton III, E. F., \& Swanson, R. A. (2014). The adult learner: The definitive classic in adult education and human resource development. New York, NY: Routledge.

Koç, M., Demirbilek, M., \& Ince, E. Y. (2015). A Needs Assessment for Academicians' Professional Development. Egitim ve Bilim, 40(177), 297-311. https://doi: 10.15390/EB.2015.2545

Lich, D. D. (2015). An Investigation into Tertiary EFL Teachers' Needs for Professional Development. In Conference paper on The 6th International Conference on" Responding to Challenges of Teaching English for Communication", At SEAMEO Regional Training Center.

Macias, A. (2017). Teacher-Led Professional Development: A Proposal for a Bottom-Up Structure Approach. International Journal of Teacher Leadership, 8(1), 76-91. Retrieved

from http://search.ebscohost.com/login.aspx?direct=true\&db=ehh\&AN=123873214\&site $=$ ehost-live

Mansory, M. (2019). The Meaning and Practice of Professionalism of EFL Teachers in the Saudi Context. English Language Teaching, 12(1), 194-203. https://doi: 10.5539/elt.v12n1p194

Moeini, H. (2008). Identifying needs: A missing part in teacher training programs. In Seminar. net (Vol. 4, No. 1). 
DEVELOPMENT

Vol. 10, No. 3, 2021, E-ISSN: 2226-6348 @ 2021 HRMARS

NaliakaMukhale, P., \& Hong, Z. (2017). Towards Improvement of Student Learning Outcomes: An Assessment of the Professional Development Needs of Lecturers at Kenyan Universities. Journal of Education and Practice, 8(12), 151-158.

Nicholls, A. (2018). Managing educational innovations. London: Routledge.

Oudah, F., \& Altalhab, S. (2018). Saudi EFL Teaching Training Programmes: Teachers' Perceptions and Needs. Theory and Practice in Language Studies, 8(11), 1407. http://dx.doi.org/10.17507/tpls.0811.04

Powell, C. G., \& Bodur, Y. (2019). Teachers' perceptions of an online professional development experience: Implications for a design and implementation framework. Teaching and Teacher Education, 77, 19-30. https://doi.org/10.1016/j.tate.2018.09.004

Raud, N., \& Orehhova, O. (2017). In-service training of teachers of english as a foreign language in Estonia: Mapping of trends and opportunities. Problems of Education in the 21st Century, 75(2), 194-203. https://doi:10.33225/pec/17.75.194

Shabani, M. B., Alibakhshi, G., Bahremand, A., \& Karimi, A. R. (2018). In-service Professional Development Scale for EFL Teachers: A Validation Study. The International Journal of Humanities, 25(3), 63-78.

Spencer, P., Harrop, S., Thomas, J., \& Cain, T. (2018). The professional development needs of early career teachers, and the extent to which they are met: a survey of teachers in England. Professional development in education,44(1), 33-46. https://doi: 10.1080/19415257.2017.1299028

Zhang, X., Admiraal, W., \& Saab, N. (2021): Teachers' motivation to participate in continuous professional development: relationship with factors at the personal and school level, Journal of Education for Teaching, https://doi.org/10.1080/02607476.2021.1942804

Zein, M. S. (2016). Professional development needs of primary EFL teachers: perspectives of teachers and teacher educators. Professional Development in Education, 43(2), 293313. https://doi: 10.1080/19415257.2016.1156013

Zulaiha, S., \& Mulyono, H. (2020). Exploring junior high school EFL teachers' training needs of assessment literacy. Cogent Education, 7(1), 1772943. https://doi.org/10.1080/2331186X.2020.1772943 